curic thiophosphate could be prepared in fairly good yield even under vigorous reaction conditions, substitution of some functional group on phenyl group greatly hindered this reaction.

[Agr. Biol. Chem., Vol. 25, No. 2, p. 150 154, 1961]

\title{
Studies on the Organophosphorus Insecticides
}

\author{
Part IV. Synthesis and Toxicity of Phosphorates and Phosphorothioates \\ Containig 1-Phenyl-2-acyl-vinyl Group \\ By Yoshihiko Nishizawa \\ Laboratory of Sumitomo Chem. Co., Ltd., Osaka \\ Received September 2, 1960
}

\begin{abstract}
The reaction of O,O-dialkyl phosphorochloridates*1) or phosphorochloridothioates with sodium salts of benzoylacetone and the reaction of trialkyl phosphites with $a$-chloro-benzoylacetone or acetophenone were attempted with a view to prepare the low toxic phosphorus insecticides containing acyl-vinyl group. It was found that the products did not have a phosphonate-form but a phosphorate-form and the phenyl-acyl-vinyl group had linkage with phosphorus atom by the enol-form of next carbonyl group of the phenyl-group.
\end{abstract}

During a course of an investigation of organophosphorus insecticides, the present author ${ }^{1)}$ found that the phosphorates containing 1-phenyl-2-carboethoxy-vinyl (II) or 1-methyl-2-phenyl-2'-carboethoxy-vinyl groups (III) are lower toxic than 1-methyl-2-carboethoxy-vinyl phosphorate (I) in Phosdrin type phosphorates, though their activity are almost of the same degree (see Table I).

G. Schrader ${ }^{2}$ also reported that O,O-diethyl-s-phenyl-cyanomethyl phosphorodithioate (V) is lower than O,O-diethyl S-phenylcyanomethyl phosphorodithioate (IV) (see Table I) .

*1) The phosphrous compounds in this paper were named according to the Drake Committee's Reports (Chem. Eng. News, 30, 4515 (1952)).

1) Y. Nishizawa, Bull. Agr. Chem. Soc. Japan, 24, 261 (1960).

2) G. Schrader, D.R.P., Nr. 1,024,509.
The present author reported already that the phosphorates containing acetyl-vinyl group (VI), (VII) have good insecticidal activity and high toxicity ${ }^{1,3)}$. So, it was considered that the introduction of phenyl group into the above phosphorates (VI), (VII) will bring the lowering of the toxicity of the compounds in these series. Then, at first, the reactions of $\mathrm{O}, \mathrm{O}$-dialkyl phosphorochloridate (VIII, $\mathrm{Y}=\mathrm{O}$ ) or phosphorochloridothioate (VIII, $\mathrm{Y}=\mathrm{S}$ ) with sodium salt of benzoylacetone $^{4)}$ (IX) and, next, the reaction of trialkyl phosphite with $\gamma$-chloro-benzoylacetone ${ }^{5}$ ) (X) were attempted according to the follow-

3) Y. Nishizawa, Jap. Pat., Announced No. Showa 32-2919 (1960).

4) L. Claisen, Ber., 38, 695 (1905).

5) A.K. Macbeth, J. Chem. Soc., 123, 1128 (1923). 
TABle I. The Toxic Dose of Phosphorus Compounds

\begin{aligned} No. & \multicolumn{1}{c}{ Formula } \\ I & $\left(\mathrm{CH}_{3} \mathrm{O}\right)_{2} \mathrm{P}(\mathrm{O}) \mathrm{OC}\left(\mathrm{CH}_{3}\right): \mathrm{CHCOOC}_{2} \mathrm{H}_{5}{ }^{1)} \\$ II & $\left(\mathrm{CH}_{3} \mathrm{O}\right)_{2} \mathrm{P}(\mathrm{O}) \mathrm{OC}\left(\mathrm{C}_{6} \mathrm{H}_{5}\right): \mathrm{CHCOOC}_{2} \mathrm{H}_{5}{ }^{1)} \\$ III & $\left(\mathrm{CH}_{3} \mathrm{O}\right)_{2} \mathrm{P}(\mathrm{O}) \mathrm{OC}\left(\mathrm{CH}_{3}\right): \mathrm{C}\left(\mathrm{C}_{6} \mathrm{H}_{5}\right) \mathrm{COOC}_{2} \mathrm{H}_{5}{ }^{1{ }^{1}} \\$ IV & $\left.\left(\mathrm{C}_{2} \mathrm{H}_{5} \mathrm{O}\right)_{2} \mathrm{P}(\mathrm{S}) \mathrm{SCH}_{2} \mathrm{CN}^{2}\right) \\$ V & $\left(\mathrm{C}_{2} \mathrm{H}_{5} \mathrm{O}\right)_{2} \mathrm{P}(\mathrm{S}) \mathrm{SCH}^{2}\left(\mathrm{C}_{6} \mathrm{H}_{5}\right) \mathrm{CN}^{2)} \\$ VI & $\left(\mathrm{CH}_{3} \mathrm{O}\right)_{2} \mathrm{P}(\mathrm{O}) \mathrm{OC}\left(\mathrm{CH}_{3}\right): \mathrm{CHCOCH}_{3}{ }^{1)} \\$ VII & $\left(\mathrm{C}_{2} \mathrm{H}_{5} \mathrm{O}\right)_{2} \mathrm{P}(\mathrm{O}) \mathrm{OC}\left(\mathrm{CH}_{3}\right): \mathrm{CHCOCH}_{3}{ }^{11}\end{aligned}$

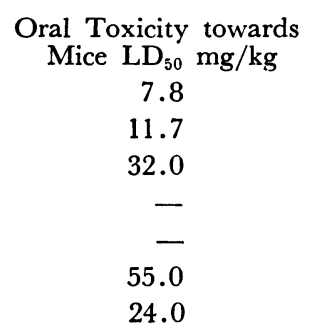

Oral Toxicity towards Rats $\mathrm{LD}_{50} \mathrm{mg} / \mathrm{kg}$

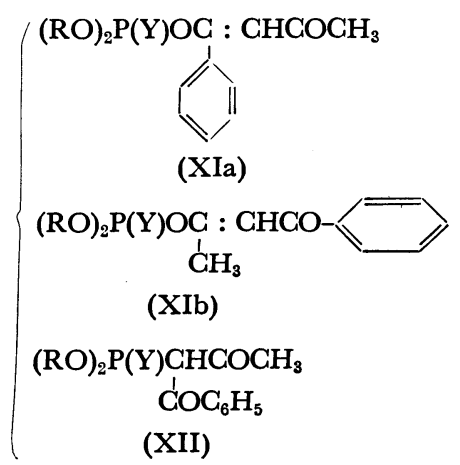

ing scheme ${ }^{3)}$, with a view to prepare the new phosphorus insecticides containing phenylacetyl-vinyl group.

All the products were liquid and purified by distillation under a reduced pressure, but the phosphorothioates contained a little oxothiol form by distillation, because in the infrared absorption spectrum of distilled phosphorothioates, $\mathbf{P}=\mathbf{O}$ streching vibration appears at $1350 \mathrm{~cm}^{-1}$, so the distilled phosphorothioates were purified again by silica-gel column-chlomatography.

In the phosphorates, the method-B gave

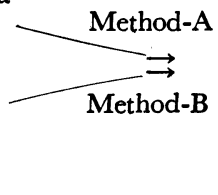

higher yield than the method-A just as shown in Table II and the experimental processes of the method-B was simpler than the method-A.

By the above reactions, three formulae were considered as main products according to the microanalytical data, namely, two of them are phosphorate form (XI), another is phosphonate form (XII) .

It was cleared by the following experimental facts that the main products of the above reactions have phosphorate or phosphorothioate form (XI) and not phosphonate form

Table II. The Yield and the Physical constants and the Microanalytical DATA OF NEW Phosphorus Compounds

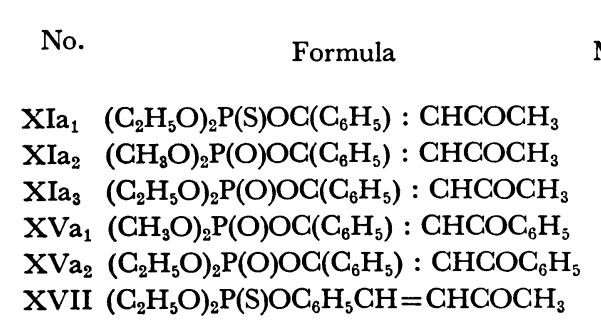

\begin{tabular}{|c|c|c|c|c|c|c|c|c|}
\hline & (\%) & B. $\mathrm{F}$ & & $n\left(t^{\circ} \mathrm{C}\right)$ & Phosph & $\operatorname{prus}(\%)$ & Sulf & $r(0$ \\
\hline A & $B$ & ${ }^{\circ} \mathrm{C}$ & $\widehat{\mathrm{mmHg}}$ & ${ }^{n} \mathrm{D}$ & Calcd. & & & und. \\
\hline 63.0 & - & $150 \sim 152$ & 0.2 & $1.5451^{(26)}$ & 10.4 & 10.8 & 10.7 & 10.5 \\
\hline 58.1 & 71.1 & $154 \sim 157$ & 1.0 & $1.5256^{(23.5)}$ & 3) 11.5 & 11.6 & - & - \\
\hline 66.8 & 81.7 & $148 \sim 151$ & 0.75 & $1.5157^{(23.5)}$ & 5) 10.4 & 10.6 & - & 一 \\
\hline - & 51.5 & - & - & $1.5652^{(26.5)}$ & 9.3 & 9.1 & - & - \\
\hline - & 60.3 & - & - & $1.5730^{(31)}$ & 8.6 & 8.8 & - & - \\
\hline 81.7 & - & - & - & $1.5700^{(24)}$ & 9.9 & 10.1 & 10.2 & 10.5 \\
\hline
\end{tabular}




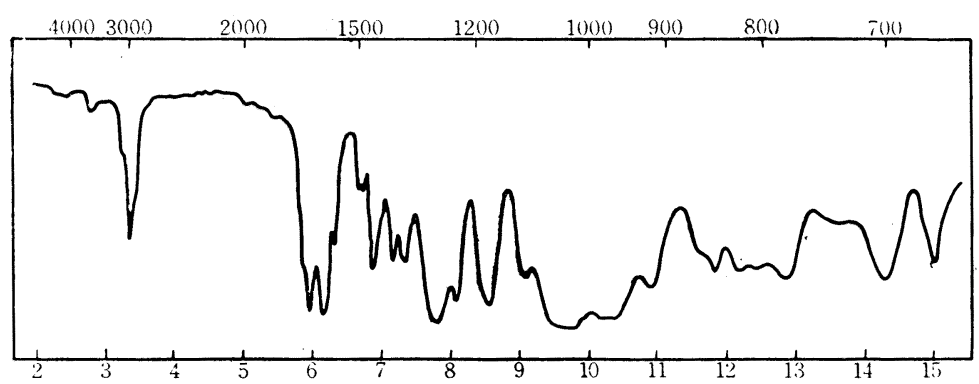

FIG. 1. The Infrared Spectrum of O, O-DiethylO-(1-phenyl-2-acetyl-vinyl) phosphoroate $\left(\mathrm{XIa}_{3}\right)$

(XII).

1) The products of the method-A showed strong infrared absorption at $1625 \mathrm{~cm}^{-1}$ which is characteristic absorption spectrum of ethylenic double bond and the absorption spectrum of carbonyl group shifted to $1680 \mathrm{~cm}^{-1}$. It was considered $^{6}$ ) that this shift occurred by the carbonyl group conjugated with some unsaturated group (see Fig. 1).

2) Alcoholysis of the products of the method-A by sodium alcoholate in a alcoholic solution gave trialkyl phosphorate or phosphorothioate and benzoylacetone. The melting point of copper salt of the benzoylacetone coincided with that of starting benzoylacetone and mixed melting point did not depress. These results showed that the products have phosphorate or phosphorothioate form ${ }^{7}$ ) (XI). (XI) .
3) The products of the method-B showed the same infrared absorption spectrum as that of the method-A and the alcoholysis of the products of method-B gave benzoylaceton which has not the chlorine atom.

Then, the formula of the products had to be determined to be (XIa) or (XIb) .

4) The infrared absorption spectra of the products showed the absorption of styryl radical at $1588 \mathrm{~cm}^{-1}$ 6) (see Fig. 1) .

5) The ozonization of the products gave the methyl glyoxal and the benzoic acid.

These results showed that the styryl radical is contained in the products.

The above experimental facts showed that the formula of the products is (XIa).

These products must have geometical isomers but they are not yet separated. These products did not show the expected lower

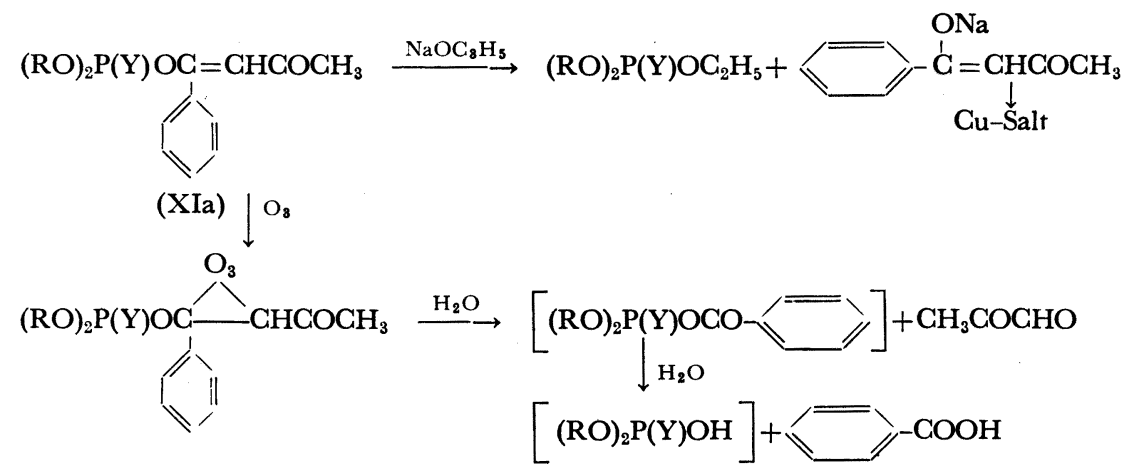

6) U.J. Bellamy, The Infra-red Spectra of Complex Molecules (1958.)

7) A.N. Pudovik, J. Gen. Chem. USSR, 26, 1605 (1956). 
Table III. The ACtivity and the Toxicity of New Phosphorus Compounds

\begin{tabular}{|c|c|c|c|}
\hline \multirow{2}{*}{ No. } & \multicolumn{2}{|c|}{$\begin{array}{l}\text { Topical application towards hibernating larvae of } \\
\text { rice stem borer (Chilo suppressalis WALKER) }\end{array}$} & \multirow{2}{*}{$\begin{array}{l}\text { Oral Toxicity towards } \\
\text { Mice } \mathrm{LD}_{50} \mathrm{mg} / \mathrm{kg}\end{array}$} \\
\hline & Kill (\%) & r/larva & \\
\hline $\mathrm{XIa}_{1}$ & 0 & 20 & 78 \\
\hline $\mathrm{XIa}_{2}$ & 100 & 0.67 & 13 \\
\hline $\mathrm{XIa}_{3}$ & 100 & 2 & 14 \\
\hline $\mathrm{XIa}_{1}$ & 50 & 6.7 & 120 \\
\hline $\mathrm{XIa}_{2}$ & 10 & 20 & 66 \\
\hline XVII & 40 & 20 & $>1000$ \\
\hline VI & 90 & 6.7 & 55 \\
\hline VII & 70 & 6.7 & 24 \\
\hline
\end{tabular}

toxicity but the activity was higher than methyl-acetyl-vinyl phosphorates (VI), (VII) (see Table III) .

The phenyl-benzoyl-vinyl phosphorates $(\mathrm{XV})$ were prepared by the above method-B, namely, the reaction of trialkyl phosphite (IX) which $\omega$-chloro- $\omega$-benzoyl-acetophenone ${ }^{8)}$ (XIV).
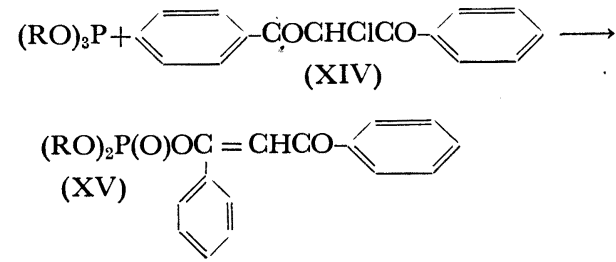

These products $(\mathrm{XV})$ shown the weaker toxicity than the products (XIa) but did not show the activity towards the insects.

The $p$-acetyl-vinyl-phenyl phosphorothioate (XVII) was also prepared by the above method-A, namely, the reaction of O,O-diethyl

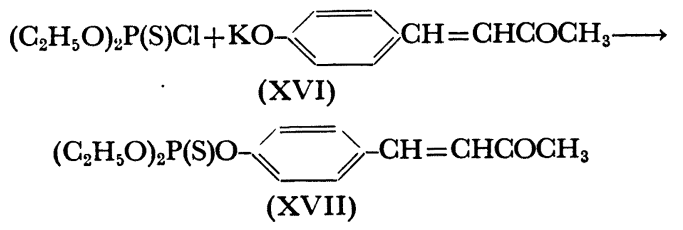

phosphorochloridate with potassium salt of p-hydroxy-benzalacetone ${ }^{10}$ ) (XVI). This prod-

8) This was prepared by the same manner as A.K. Macbeth's method ${ }^{3}$ ), namely, the reaction of $\omega$-benzoyl acetophenone $\left.{ }^{9}\right)$ with sulfaryl chloride in ether solution. m.p. $93 \sim 94^{\circ} \mathrm{C}$ (recryst. from ethanol).

9) L. Claisen, Ber. 38, 696 (1905) .

10) J.S. Buck, J. Chem. Soc., 121, 1101 (1922). uct showed the weakest toxicity and activty in this series. The above two compounds $(\mathrm{XV}),(\mathrm{XVII})$ could not be distilled without the decomposition, so, the products were purified by silica-gel column-chromatography.

The yield, the physical constants and the microanalytical data of the new phosphorus compounds were shown in Table II, and the activity and the toxicity were also shown in Table III.

\section{EXPERIMENTAL}

1) The preparation of 0,0-diethyl 0-(1-phenyl-2acetyl-vinyl) phosphorothioate $\left(\mathrm{XIa}_{1}\right)$ by the methodA.

To a suspension of $12.6 \mathrm{~g}(0.2 \mathrm{M})$ of sodium ethoxide in $300 \mathrm{ml}$ of anhydrous benzene, there was added gradually $32.4 \mathrm{~g}(0.2 \mathrm{M})$ of benzoylacetone. The solution became to sirup after two hours with stirring at $50^{\circ} \mathrm{C}$ and then $37.7 \mathrm{~g}(0.2 \mathrm{M})$ of O,O-diethyl phosphorochloridothioate was added to the reaction mixture and refluxed for eight hours at $80^{\circ} \mathrm{C}$. The reaction mixture was cooled, washed with water and dried over anhydrous sodium sulfate. After removal of the benzene, the residual oil was distilled at $150 \sim 152^{\circ} \mathrm{C} /$ $0.2 \mathrm{mmHg}$.

The distilled phosphorothioate was dissolved in $200 \mathrm{ml}$ of chloroform and treated with silica-gel column. The pure phosphorothioate was obtained $18.8 \mathrm{~g}(63 \%) ; n_{\mathrm{D}}^{26} 1.5451$.

Anal. Calcd. for $\mathrm{C}_{14} \mathrm{H}_{10} \mathrm{O}_{3} \mathrm{PS} ; \mathrm{P}, 10.4 ; \mathrm{S}, 10.7 \%$. Found.; P, 10.8; S, $10.5 \%$

2) The preparation of 0,0-dimethyl 0-(1-phenyl-2acethyl-vinyl) phosphorate $\left(\mathrm{XIa}_{2}\right)$ by method-B Twelve point four grams of trimethyl phosphite was 
added gradually to a solution of $19.7 \mathrm{~g}(0.1 \mathrm{M})$ of 2-chloro-benzoylacetone in $50 \mathrm{ml}$ of ether with stirring and sufficient cooling. The temperature of the reaction mixture was raised to $40^{\circ} \mathrm{C}$. After refluxing for one hour, the ether was distilled off, and the residual colorless oil was fractionated in vacuo, b.p. $154 \sim 157^{\circ} \mathrm{C} /$ $1 \mathrm{mmHg}$. Yielded $19.2 \mathrm{~g} \cdot n_{\mathrm{D}}^{23.5} 1.5256$.

Anal. Calcd. for $\mathrm{C}_{12} \mathrm{H}_{15} \mathrm{O}_{5} \mathrm{P} ; \mathrm{P}, 11.5 \%$ Found.; P, $11.6 \%$

3) The preparation of 0,0 -diethyl 0 -(p-acetylvinylphenyl) phosphorothioate (XVII)

A mixture of $32.4 \mathrm{~g}(0.2 \mathrm{M})$ of $p$-hydroxy-benzalacetone, $27.6 \mathrm{~g}$ of anhydrous potassium carbonate and $100 \mathrm{ml}$ of methyl isobutyl ketone was heated at about $100^{\circ} \mathrm{C}$. Carbon dioxide and water were eliminated and the water was removed from the reaction mixture by azeotropic distillation, and then the reaction mixture was cooled at $60^{\circ} \mathrm{C}$. There was added gradually $37.7 \mathrm{~g}$ $(0.2 \mathrm{M})$ of O,O-diethyl phosphorochloridothioate to the mixture by stirring. After putting of the phosphorochloridothioate in excess, stirring was further continued for 8 hours at $60 \sim 80^{\circ} \mathrm{C}$ to complete the reaction. Water was added to dissolve the precipitated inorganic salt and organic layer was separated, washed with water and dried over anhydrous sodium sulfate. After removal of the methyl isobutyl ketone in vacuo, $51.3 \mathrm{~g}$ of this red oily product was obtained. For further purification, the crude product was purified by column-chromatography using active carbon and alumina, obtaining a pale yellow oily product having a refractive index $n_{\mathrm{D}}^{24} 1.5700$.

Anal. Calcd. for $\mathrm{C}_{14} \mathrm{H}_{19} \mathrm{O}_{4} \mathrm{PS} ; \mathrm{P}, 9.9 ; \mathrm{S}, 10.2 \%$

Found.; P, 10.1; S, 10.5\%

4) Alcoholysis of 0,0-diethyl 0-(1-phenyl-2-acetylvinyl) phosphorate ( $\left.\mathrm{XIa}_{3}\right)$

- To a solution of sodium alcoholate prepared form $2.3 \mathrm{~g}$ of sodium in $200 \mathrm{ml}$ of absolute alcohol was added to $29.8 \mathrm{~g}$ of O,O-diethyl O-(1-phenyl-2-acetyl vinyl) phosphorate $\left(\mathrm{XIa}_{3}\right)$ at room temperature. After refluxing for one hour, the reaction mixture was neutralized with $6.0 \mathrm{~g}$ of acetic acid and the alcohol was evaporated.

Ether and water were added to the residue, the ether layer was washed with water and shaked with saturated aqueous solution of copper acetate, the crystals were obtained, yield $16.5 \mathrm{~g}$. These crystals melted at $194 \sim 195^{\circ} \mathrm{C}$ (from methyl alcohol). A mixture of the crystals and the authentic specimen ${ }^{11}$ 11) W. Wislicenus, Ber., 35, 545 (1902). which was prepared by benzoylacetone and solution of copper acetate melted at $195 \sim 196^{\circ} \mathrm{C}$.

Anal. Calcd. for $\left(\mathrm{C}_{10} \mathrm{H}_{8} \mathrm{O}_{2}\right)_{2} \mathrm{Cu} \cdot \mathrm{CH}_{3} \mathrm{OH} ; \mathrm{C}, 60.34$; $\mathrm{H}, 5.26 \%$

Found.; C, $60.71 ; \mathrm{H}, 5.44 \%$

Ether solution after separating the copper salt was washed with water and dried over anhydrous sodium sulfate. After removal of the ether, the residual oil was distilled in vacuo, triethyl phosphorate was obtained at $100 \sim 105^{\circ} \mathrm{C} / 25 \mathrm{mmHg}$. Yield $9.6 \mathrm{~g} n_{\mathrm{D}}^{21} 1.4060$. Anal. Calcd. for $\mathrm{C}_{6} \mathrm{H}_{15} \mathrm{O}_{4} \mathrm{P} ; \mathrm{P}, 17.0 \%$

Found.; $\mathrm{P}, 17.2 \%$

Alcoholysis of O,O-diethyl O- (1-phenyl-2-acetylvinyl) phosphorothioate gave the same results, namely, benzoylacetone and triethyl phosphorothioate (b.p. 94 $95^{\circ} \mathrm{C} / 15 \mathrm{mmHg}$ ) were obtained.

5) Ozonization of 0,0-diethyl 0-(1-phenyl-2-acetyl vinyl) phosphorate (XIas).

Ozonized oxygen $(0.1 \sim 0.05 \%$ ozone) was passed for 24 hours into a solution of $8.4 \mathrm{~g}$ of the phosphorate $\left(\mathrm{XIa}_{3}\right)$ in $20 \mathrm{ml}$ of dry carbon tetrachloride cooled with a mixture of ice and salt. After suction-filtering of the solvent in vacuo, the ozonides were decomposed with water while heating on a boiling water for five hours. The water solution was cooled, white crystals of benzoic acid was separated. Yielded 2.1 g. m.p. $121^{\circ} \mathrm{C}$.

To the filtrate solution, there was added sulfuric acidic alcohol solution of phenylhydrazine, phenylhydrazone of methyl glyoxal was precipitated, yield 4.4 g. m.p. $147 \sim 148^{\circ} \mathrm{C}$.

Anal. Calcd. for $\mathrm{C}_{15} \mathrm{H}_{10} \mathrm{~N}_{4} ; \mathrm{C}, 71.43 ; \mathrm{H}, 6.35 ; \mathrm{N}$, $22.22 \%$

Found.; C, 71.66; H, 6.18; N, 22.80\%

Acknowledgements The author wishes to express his thanks to Professor Shinichiro Fuzise and Professor Taro Yamazaki in Tohoku University for helpful suggestions in the preparation of this manuscript. He also wishes to thank the Sumitomo Chem. Co., Ltd. for permission to publish this work. $\mathrm{He}$ is indebted to co-workers in the pesticidal, the biological and the microanalytical sections in this laboratory. He also wishes to express his thanks to Mr. M. Nakagawa for his earnest assistance. 